\title{
SOLUTION STRENGTHENING AND AGE HARDENING CAPABILITY OF Al-Mg-Mn ALLOYS WITH SMALL ADDITIONS OF Cu
}

\author{
Z. Zhu, M.J. Starink \\ Materials Research Group, School of Engineering Sciences, University of Southampton, \\ Southampton S017 1BJ, UK
}

\begin{abstract}
Nine Al-(1-3)Mg-(0-0.4)Cu-0.15Si-0.25Mn (in wt\%) alloys with potential applications in both packaging and automotive industries have been investigated. Tensile testing showed that solution strengthening is in good approximation linearly proportional to the $\mathrm{Mg}$ content. Mechanical testing and microstructural examinations of aged samples indicate that $\mathrm{Mg}_{2} \mathrm{Si}$ phase precipitates contribute to age hardening of $\mathrm{Cu}$-free alloys, whilst both $\mathrm{Mg}_{2} \mathrm{Si}$ phase and $\mathrm{S}\left(\mathrm{Al}_{2} \mathrm{CuMg}\right)$ phases contribute to that of $\mathrm{Cu}$-containing alloys. The age hardening capability is critically influenced by solution treatment temperature: increasing the solution treatment temperature from 500 to $550^{\circ} \mathrm{C}$ results in a marked increase in rate of hardening for $\mathrm{Cu}$ containing alloys and solution treatment at about $550^{\circ} \mathrm{C}$ or higher is needed to allow $\mathrm{Mg}_{2} \mathrm{Si}$ phase precipitation during ageing in $\mathrm{Cu}$-free alloys with $\mathrm{Mg}$ content of about $2 \%$ or higher.
\end{abstract}

\section{Introduction}

Aluminium alloys are used in a wide range of applications in transport, packaging, building and general engineering sectors. The alloys studied in this work, with compositions in the range Al-(1-3)wt $\% \mathrm{Mg}-0.2 \mathrm{wt} \% \mathrm{Mn}-0.2 \mathrm{wt} \% \mathrm{Fe}-0.2 \mathrm{wt} \% \mathrm{Si}-(0-0.4) \mathrm{wt} \% \mathrm{Cu}$, encompass alloy compositions that are employed in canstock and compositions that have potential for application in cars. Al-Mn based (3XXX) and Al-Mg based (5XXX) alloys have been widely used in beverage cans for decades $[1,2,3,4]$. Specifically, AA3104/3004 (compositions typically around Al-1Mg-1Mn-0.2Cu(0.3-0.6)Si-0.5Fe) and AA5182 (composition around Al-4Mg-0.3Mn-0.1Cu-0.2Si-0.2Fe) alloys have long been used as can body stock and can end stock, respectively. Although the market now is mature, there is a fierce competition coming from alternative materials such as steel, polyethylene tetraphthalate (PET) etc. [1,2]. The solution to improving the competitiveness of Al alloys is to reduce the costs by improving process efficiency and innovations in weight reduction or downgauging of the canstock $[1,2,4]$. Therefore, it is essential to understand (both qualitatively and quantitatively) the relation between processing, microstructure and properties.

In recent decades, there is a trend in the automobile industry to use aluminium alloys as car body panels to reduce weight and thus improve fuel economy and emissions [5]. Both 5XXX Al-Mg alloys, which are mostly non-heat-treatable, and heat-treatable $\mathrm{Al}-\mathrm{Cu}, \mathrm{Al}-\mathrm{Mg}-\mathrm{Si}-\mathrm{Cu}$ and $\mathrm{Al}-\mathrm{Mg}-\mathrm{Si}$ alloys of 2XXX and 6XXX series are used. Although the Al-Mg-Mn 5XXX alloys have good formability, they have a relatively low strength with a tendency of Lüders band formation [6,7], which restricts their use to interior structural applications [5]. Hence, for automotive applications, there is a growing trend to exploit new alloys [8,9]. 5XXX alloys (especially AA5182 and AA5052 (composition around $\mathrm{Al}-3 \mathrm{Mg}-0.3 \mathrm{Mn}-0.1 \mathrm{Cu}-0.2 \mathrm{Si}$ )) with small $\mathrm{Cu}$ additions are very promising candidates for these applications because of their excellent formability, good strength and the 
benefits of precipitation hardening during paint-baking due to $\mathrm{Cu}$ additions [10]. However, precipitation hardening induced by $\mathrm{Cu}$ additions may make the interactions between work hardening, recovery and precipitation more complicated during processing.

Canstock sheet production involves a number of thermomechanical processing steps, starting with DC ingot casting followed by homogenisation, hot rolling, annealing and cold rolling. Homogenisation usually occurs at two temperatures, e.g. starting at about $570^{\circ} \mathrm{C}$ followed by slow cooling to about $510^{\circ} \mathrm{C}$. Its main objectives in the can making process are the elimination of microsegregation, the transformation of the $\mathrm{Al}_{6}(\mathrm{Fe}, \mathrm{Mn})$ coarse particles to $\alpha-\mathrm{Al}_{12}(\mathrm{Fe}, \mathrm{Mn})_{3} \mathrm{Si}$ particles [11] and the redistribution of $\mathrm{Mn}$ from solid solution to coarse particles and dispersoids. During the relatively slow commercial heat up of an ingot, a uniform distribution of $\mathrm{Mg}, \mathrm{Cu}$ and $\mathrm{Si}$ can be achieved after heating up to $500^{\circ} \mathrm{C}$ [12]. A range of further hot and cold rolling steps follow, and can bodies are produced by a draw \& iron (D\&I) process. The can body needs to be able to withstand a minimum dome reversal pressure, and have vertical load bearing capacity, making strength an important consideration too. Higher strength enables thinner sheet to be used and hence a more efficient use of material in the fabrication of the product. Surface qualities of the sheet are also important, both in terms of surface finish for the product and for good frictional characteristics between the sheet surface and the forming dies.

The alloys used for the above-mentioned canstock and automotive applications are generally based on Al-Mg-Mn alloys with small additions of $\mathrm{Cu}$. The alloys are warm or cold rolled to achieve thin gauge. During the processing of alloys with $\mathrm{Cu}$ additions, precipitation of strengthening phases occurs during hot and cold rolling as well as during heat treatment after cold rolling [13]. In both cases, precipitation will change the yield stress and the work hardening, which will affect subsequent further working of the alloys. After cold rolling, the alloys for beverage can application are used in a work hardened condition, but for the car body application, they will be supplied to car manufacturers with $\mathrm{O}$ temper (annealed) due to the higher requirement of excellent formability during car body forming. For both applications, coating/painting and baking are needed as a final procedure. Both recovery and precipitation will occur during the baking process of the cold worked alloys.

The present paper reports work on nine alloys in the range $\mathrm{Al}-(1-3) \mathrm{wt} \% \mathrm{Mg}-0.2 \mathrm{wt} \% \mathrm{Mn}-0.2 \mathrm{wt} \% \mathrm{Fe}-$ $0.2 \mathrm{wt} \% \mathrm{Si}-(0-0.4) \mathrm{wt} \% \mathrm{Cu}$. These low $\mathrm{Cu}$ additions are effectively microalloying additions, causing changes in the amount of secondary phases that are very small compared with the amounts present without the $\mathrm{Cu}$ additions [14]. As part of a larger study into modelling of microstructure evolution and mechanical properties, we here present an analysis of the solution strengthening and age hardening capability of the alloys after solution treatment.

\section{Experimental}

In this study, nine Al-(1-3)Mg-(0-0.4)Cu-Mn-Fe-Si alloys (in wt\%) were investigated. The alloys were produced at the former Alcan Banbury Labs, Banbury, UK, and their compositions are shown in Table I. All alloys were direct chill (DC) cast. The cast ingots were preheated and homogenised at $540^{\circ} \mathrm{C}$, and subsequently hot rolled down to $5 \mathrm{~mm}$ in thickness. After that, the hot rolled sheets were solution treated at $500^{\circ} \mathrm{C}$ for 20 minutes, followed by cold rolling to $10 \%$ and $40 \%$ reduction. Transmission electron microscopy and electron backscatter diffraction studies of the as cold-rolled 
material were reported elsewhere [15]. Specimens of $40 \%$ cold rolled alloys were re-solution treated at $500^{\circ} \mathrm{C} / 30 \mathrm{~min}$ and $550^{\circ} \mathrm{C} / 30 \mathrm{~min}$ for mechanical testing and age hardening experiments.

The tensile testing specimens were designed based on and within the specification of the ASTME8M standard. To provide a valid measurement of sample elongation and elongation to failure, samples should fail in a smooth section between the points of attachment of the extensometer. To ensure this, a small modification of the design of tensile specimens was adopted which entailed a small and gradual change in the cross sectional area of about $0.8 \%$ such that the minimum cross sectional area is located in the middle of the gauge length of the sample. Therefore, a specimen with this geometry is prone to fracture at the middle of the gauge length during tensile testing due to the highest stress occurring in this section. The tensile axis is taken in the longitudinal (L) direction (i.e. the rolling direction). Tensile testing was performed on the freshly solution treated samples solutionised at $500^{\circ} \mathrm{C}$ to evaluate solution strengthening due to $\mathrm{Mg}$ and $\mathrm{Cu}$. Tensile tests were performed using an 8800 series Instron machine at a constant strain rate of $0.001 \mathrm{~s}^{-1}$. For each condition usually two tests were performed. The difference in elongation to failure between two tests is on average $3 \%$; i.e. the confidence in the reported average is about $1.5 \%$. The difference in $0.2 \%$ proof strength between two tests is on average $3 \mathrm{MPa}$, i.e. the confidence in the reported average is about $1.5 \mathrm{MPa}$.

For age-hardening tests, solution treated samples were isothermally aged at $170^{\circ} \mathrm{C}$ in an oven. Hardness tests were performed using a micro-Vickers hardness tester with $1 \mathrm{~kg}$ load held for $15 \mathrm{~s}$. The mean of 5 indentations was taken as the hardness of the corresponding condition.

Table I Compositions of the alloys studied (in wt\%)

\begin{tabular}{|c|c|c|c|c|c|c|}
\hline Alloy No. & $\mathrm{Mg}$ & $\mathrm{Cu}$ & $\mathrm{Mn}$ & $\mathrm{Fe}$ & $\mathrm{Si}$ & $\mathrm{Al}$ \\
\hline $\mathrm{A} 1$ & 1.02 & $<.01$ & 0.25 & 0.22 & 0.16 & \\
A2 & 1.96 & $<.01$ & 0.25 & 0.20 & 0.15 & \\
A3 & 2.95 & $<.01$ & 0.24 & 0.20 & 0.15 & \\
A4 & 1.01 & 0.18 & 0.26 & 0.21 & 0.14 & \\
A5 & 1.91 & 0.18 & 0.25 & 0.19 & 0.14 & bal. \\
A6 & 2.99 & 0.19 & 0.24 & 0.19 & 0.15 & \\
A7 & 1.03 & 0.39 & 0.26 & 0.20 & 0.14 & \\
A8 & 1.98 & 0.39 & 0.25 & 0.21 & 0.15 & \\
A9 & 2.9 & 0.4 & 0.25 & 0.19 & 0.15 & \\
\hline
\end{tabular}

For analyses by differential scanning calorimetry (DSC), small disks were prepared. The DSC experiments were conducted in a Perkin-Elmer Pyris 1 DSC. All experiments were run at a constant heating rate of $10^{\circ} \mathrm{C} / \mathrm{min}$. Details and methodology for DSC experiments and baseline correction are provided elsewhere [16]. In the present alloys, the heat effects are very small, and hence baseline correction proved challenging. In the presented DSC thermograms, baseline correction using a linear function was conducted, and remaining uncertainties on position of baseline are in the order of $2 \mathrm{~mW} / \mathrm{g}$ in the range up to $400^{\circ} \mathrm{C}$.

Samples for analysis by a field emission gun scanning electron microscope (FEG-SEM) were cut from cold rolled sheets with $10 \%$ reduction and then cold mounted. Subsequently, they were ground and polished using standard procedures. FEG-SEM observations were conducted on a JSM-6500 
scanning electron microscope for intermetallics analysis. The FEG-SEM was equipped with an energy dispersive spectrometer (EDS) for compositional analysis.

\section{$3 \quad$ Results and discussion}

\subsection{Intermetallic particles}

Intermetallic analysis by SEM/EDS was performed on the cold worked samples of alloys A1, A2, A3, A4, A5 and A9. Cold-rolled alloy A9 was selected for detailed intermetallics analyses, and example of particles observed by SEM is presented in Fig. 1. The particles are generally aligned in the rolling direction. For one group of particles, which appear bright in the backscatterred electron imaging (BEI) mode, the EDS results reveal the presence of $\mathrm{Cu}, \mathrm{Fe}, \mathrm{Mn}$ and $\mathrm{Si}$. A plot of $\mathrm{Si}:(\mathrm{Fe}+\mathrm{Mn}+\mathrm{Cu})$ ratio vs. $\mathrm{Al}:(\mathrm{Fe}+\mathrm{Mn}+\mathrm{Cu})$ ratio (Fig. 2) shows that these particles can be classified into two groups. Thermodynamic simulations (see below) and various microstructural studies on similar alloys (see e.g. [11,17]) have indicated that these alloys contain two Mn and Fe containing phases: $\mathrm{Al}_{6}(\mathrm{Fe}, \mathrm{Mn}, \mathrm{Cu})$ and $\mathrm{Al}_{12}(\mathrm{Fe}, \mathrm{Mn}, \mathrm{Cu})_{3} \mathrm{Si}$ (also known as the cubic alpha phase). In Group I, the $\mathrm{Si}:(\mathrm{Fe}+\mathrm{Mn}+\mathrm{Cu})$ ratio is about 0 and the $\mathrm{Al}:(\mathrm{Fe}+\mathrm{Mn}+\mathrm{Cu})$ ratio is about 5 7.5. The particles in this group are identified as $\mathrm{Al}_{6}(\mathrm{Fe}, \mathrm{Mn}, \mathrm{Cu})$. Most of the brighter particles are located in this group. In the other group (Group II), the $\mathrm{Si}(\mathrm{Fe}+\mathrm{Mn}+\mathrm{Cu})$ ratio is about $0.25 \sim 0.3$ whilst the $\mathrm{Al}:(\mathrm{Fe}+\mathrm{Mn}+\mathrm{Cu})$ ratio is about 7 8. The particles in group II therefore are identified as $\mathrm{Al}_{12}(\mathrm{Fe}, \mathrm{Mn}, \mathrm{Cu})_{3} \mathrm{Si}$. The $\mathrm{Al}:(\mathrm{Fe}+\mathrm{Mn}+\mathrm{Cu})$ ratio obtained from EDS analysis is slightly higher than that in the stoichiometry of $\mathrm{Al}_{12}(\mathrm{Fe}, \mathrm{Mn}, \mathrm{Cu})_{3} \mathrm{Si}$, which is 4 . This may be due to the interactions of the surrounding Al matrix and the particles analysed. A third type of particles found in alloy A9 appears darker in the BEI images. The EDS analysis in the SEM shows it contains $\mathrm{Mg}$ and $\mathrm{Si}$ elements, with no significant amounts of other alloying elements being detected, and it may be identified as $\mathrm{Mg}_{2} \mathrm{Si}$ phase. The observations on the presence of these particles are summarised in Table 2.

Table 2 Thermodynamic equilibrium prediction of particle content at $500^{\circ} \mathrm{C}$ and $540^{\circ} \mathrm{C}$, and particles detected in SEM/EDS experiments (+: detected, -:not detected, blank: alloy not studied by SEM).

\begin{tabular}{ccccccc}
\hline Alloys & \multicolumn{3}{c}{$\mathrm{Al}_{12}(\mathrm{Fe}, \mathrm{Mn})_{3} \mathrm{Si}$} & \multicolumn{3}{c}{$\mathrm{Mg}_{2} \mathrm{Si}$} \\
& $540^{\circ} \mathrm{C}$ & $500^{\circ} \mathrm{C}$ & exp. & $540^{\circ} \mathrm{C}$ & $500^{\circ} \mathrm{C}$ & exp. \\
$\mathrm{A} 1$ & 0.86 & 1.349 & + & 0 & 0 & - \\
$\mathrm{A} 2$ & 0.78 & 0 & + & 0 & 0.295 & + \\
$\mathrm{A} 3$ & 0 & 0 & + & 0.268 & 0.357 & + \\
$\mathrm{A} 4$ & 0.67 & 1.167 & + & 0 & 0 & - \\
$\mathrm{A} 5$ & 0.73 & 0 & + & 0 & 0.263 & + \\
$\mathrm{A} 6$ & 0 & 0 & & 0.271 & 0.358 & \\
$\mathrm{~A} 7$ & 0.780 & 1.238 & & 0 & 0 & \\
$\mathrm{~A} 9$ & 0 & 0 & + & 0.263 & 0.355 & + \\
\hline
\end{tabular}

It should also be noted that the occurrence of variable amounts of oxygen in the EDS spectrum for $\mathrm{Mg}_{2} \mathrm{Si}$ phase was noted. It has been mentioned in the literature that $\mathrm{Mg}_{2} \mathrm{Si}$ phase decomposes in water [18], and it was found that $\mathrm{Mg}_{2} \mathrm{Si}$ particles might begin to dissolve during water polishing 
[19]. The reason why it decomposes or dissolves in water may be explained by the following reaction [20]:

$$
\mathrm{Mg}_{2} \mathrm{Si}+4 \mathrm{H}_{2} \mathrm{O} \rightarrow \mathrm{SiH}_{4}(\mathrm{~g})+2 \mathrm{Mg}(\mathrm{OH})_{2}
$$

And the following reactions may further occur under certain conditions:

$$
\begin{aligned}
& \mathrm{Mg}(\mathrm{OH})_{2} \rightarrow \mathrm{MgO}+\mathrm{H}_{2} \mathrm{O} \\
& \mathrm{SiH}_{4}+2 \mathrm{O}_{2} \rightarrow \mathrm{SiO}_{2}+2 \mathrm{H}_{2} \mathrm{O}
\end{aligned}
$$

Therefore, $\mathrm{Mg}_{2} \mathrm{Si}$ may be dissolved during water polishing. (To avoid the decomposition of $\mathrm{Mg}_{2} \mathrm{Si}$ during polishing, alcohol instead of water may be used, but this was not applied in the present work.)

Prediction of phase diagram can be achieved through computational thermodynamics based on calculating the free energy of co-existing phases present in a system by minimising the Gibbs free energy. In this study, some thermodynamic predictions made by MTDATA software will be used. From the results of the thermodynamic calculations, three types of intermetallics may form during solution treatment depending on alloy composition: $\mathrm{Al}_{6}(\mathrm{Fe}, \mathrm{Mn}), \mathrm{Al}_{12}(\mathrm{Fe}, \mathrm{Mn})_{3} \mathrm{Si}$ and $\mathrm{Mg}_{2} \mathrm{Si}$. $\mathrm{Al}_{6}(\mathrm{Fe}, \mathrm{Mn})$ is predicted to be present in all the alloys at the solutionising temperatures $500^{\circ} \mathrm{C}$ and $540^{\circ} \mathrm{C}$ and the predicted amounts of $\mathrm{Al}_{12}(\mathrm{Fe}, \mathrm{Mn})_{3} \mathrm{Si}$ and $\mathrm{Mg}_{2} \mathrm{Si}$ are listed in Table 2, together with the results of experimental observations of these two phases.

The thermodynamic model predictions and SEM/EDS experimental results are in many aspects consistent with each other except for that thermodynamic model predicts that at $500^{\circ} \mathrm{C}$ cubic alpha particles are present only in the alloys with $1 \mathrm{wt} \% \mathrm{Mg}$, and for alloys with higher $\mathrm{Mg}$ content, no such particles are predicted. However, cubic alpha phase was detected in all the alloys studied.

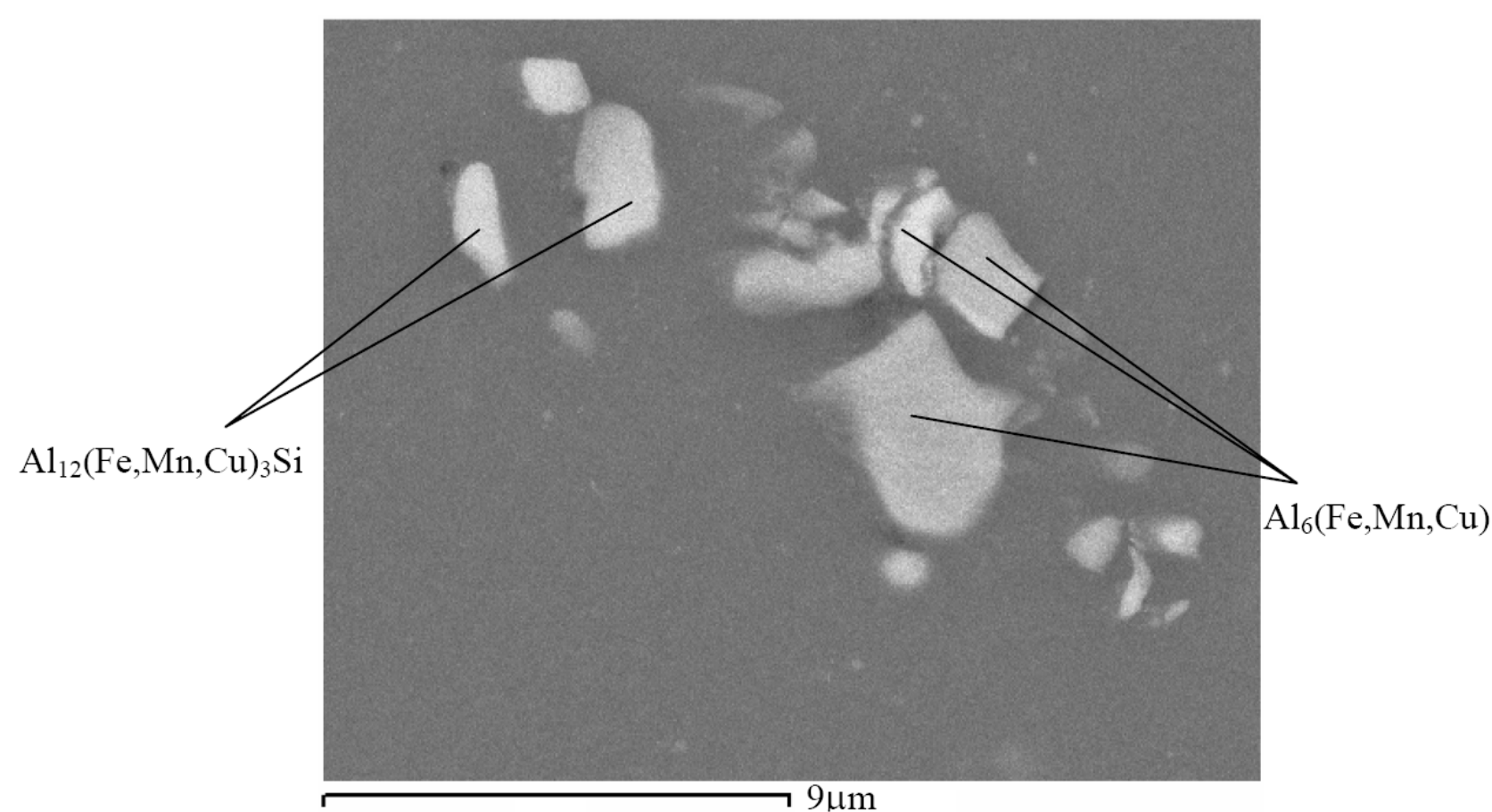

Fig. 1 SEM micrograph of the bright particles identified in the cold-rolled alloy A9 (BEI mode). 


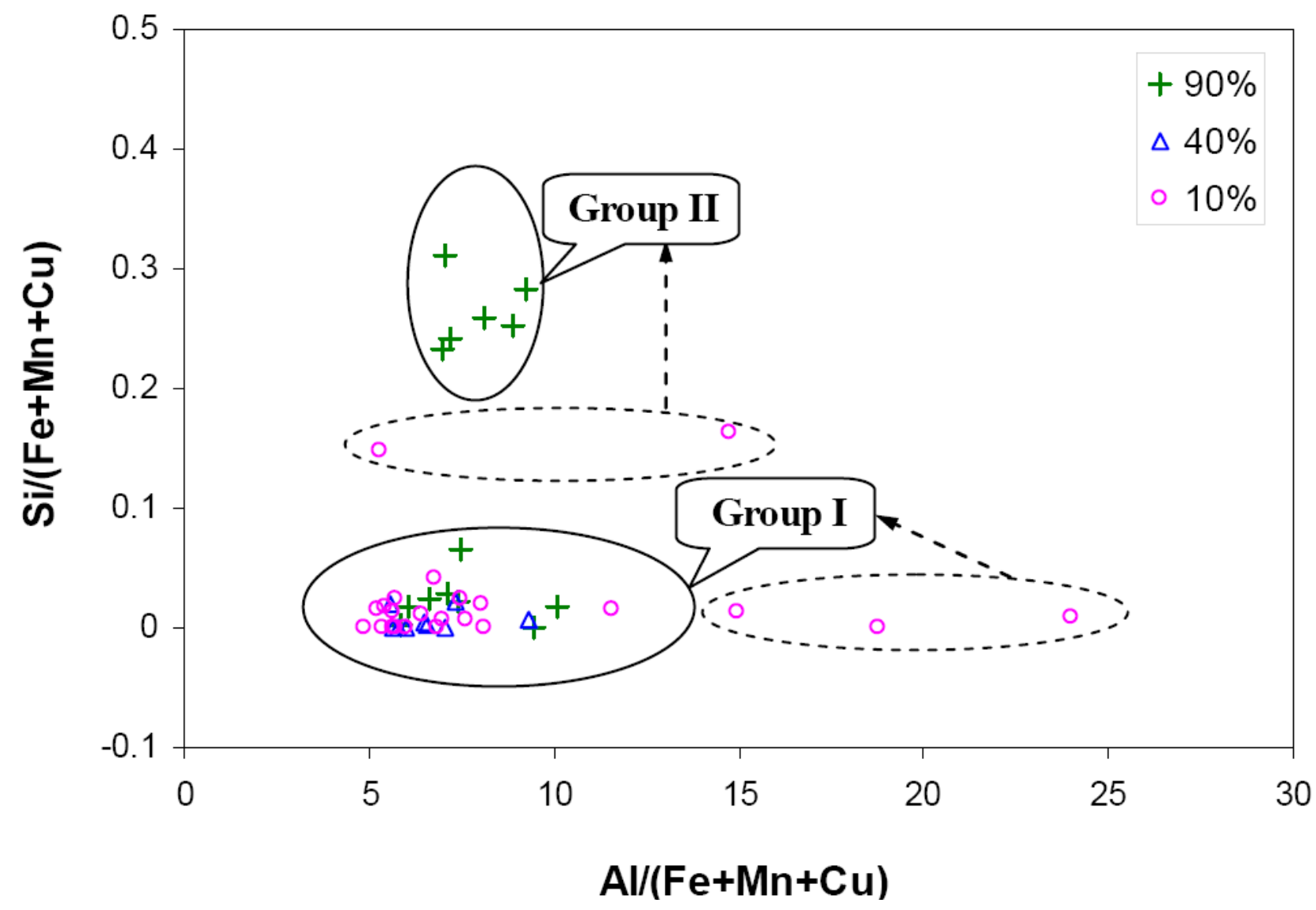

Fig. 2 The $\mathrm{Si}:(\mathrm{Fe}+\mathrm{Mn}+\mathrm{Cu})$ ratio vs. the $\mathrm{Al}:(\mathrm{Fe}+\mathrm{Mn}+\mathrm{Cu})$ ratio for the bright particles in alloy $\mathrm{A} 9$ in 3 conditions. $+: 10 \%$ cold-worked, $\Delta: 40 \%$ cold-worked and o : $90 \%$ cold-worked. Compositions fall into two groups (see text).

\subsection{Strength of solution treated alloys}

The results of tensile tests of the alloys in solution treated condition (solution treatment temperature $500^{\circ} \mathrm{C}$ ) are presented in Fig. 3 and Fig. 4. The results show that increasing the Mg content by $1 \mathrm{wt} \%$ has a strong influence on the yield strength, with increasing $\mathrm{Cu}$ content by $0.2 \mathrm{wt} \%$ causing a limited but detectable increase in the yield strength. Fig. 5 shows that, in common with many alloy systems, the elongation to failure tends to decrease with increasing yield strength. $\mathrm{Cu}$ addition appears to slightly increase the ductility at equivalent yield strength.

In order to model the yield strength of these alloys in worked and subsequently aged conditions, the following contributions have to be considered:

- Solid-solution strengthening, which is here mainly due to $\mathrm{Mg}$

- Dislocation strengthening, i.e. work hardening \& recovery

- Precipitation hardening

- Grain boundary strengthening

- Base strength

In the case of multicomponent alloys, a number of models [21,22,23,24,25,26,27] have been proposed to determine the strengthening effect due to dissolved alloying elements. A general form 
for the increment in the critical resolved shear stress (CRSS) due to solution strengthening, $\Delta \tau_{\mathrm{ss}}$, on the solute concentration is:

$$
\Delta \tau_{s s}=\sum k_{j} c_{j}^{n_{s s}}
$$

where $k$ is a constant related to the properties of the related solute $j, c$ is the solute concentration. Theoretical treatments indicate $n$ could equal 2/3, 1 or $1 / 2$ [24]. The yield strength of solution treated alloys, that have negligible strengthening contributions due to dislocations, is written as:

$$
\sigma_{r e x}=\sigma_{g b}+M\left(\tau_{o}+\Delta \tau_{s s}\right)
$$

where $\Delta \sigma_{\mathrm{gb}}$ is the strength increment due to the grain boundaries, $M$ is a crystallographic orientation factor (often termed the Taylor factor) which is related to texture and the orientation of the specimen, $\tau_{\mathrm{o}}$ is critical resolved shear stress of pure Al. The self-consistent modelling of the plastic deformation of FCC polycrystals gives $M=2.6$ [28].

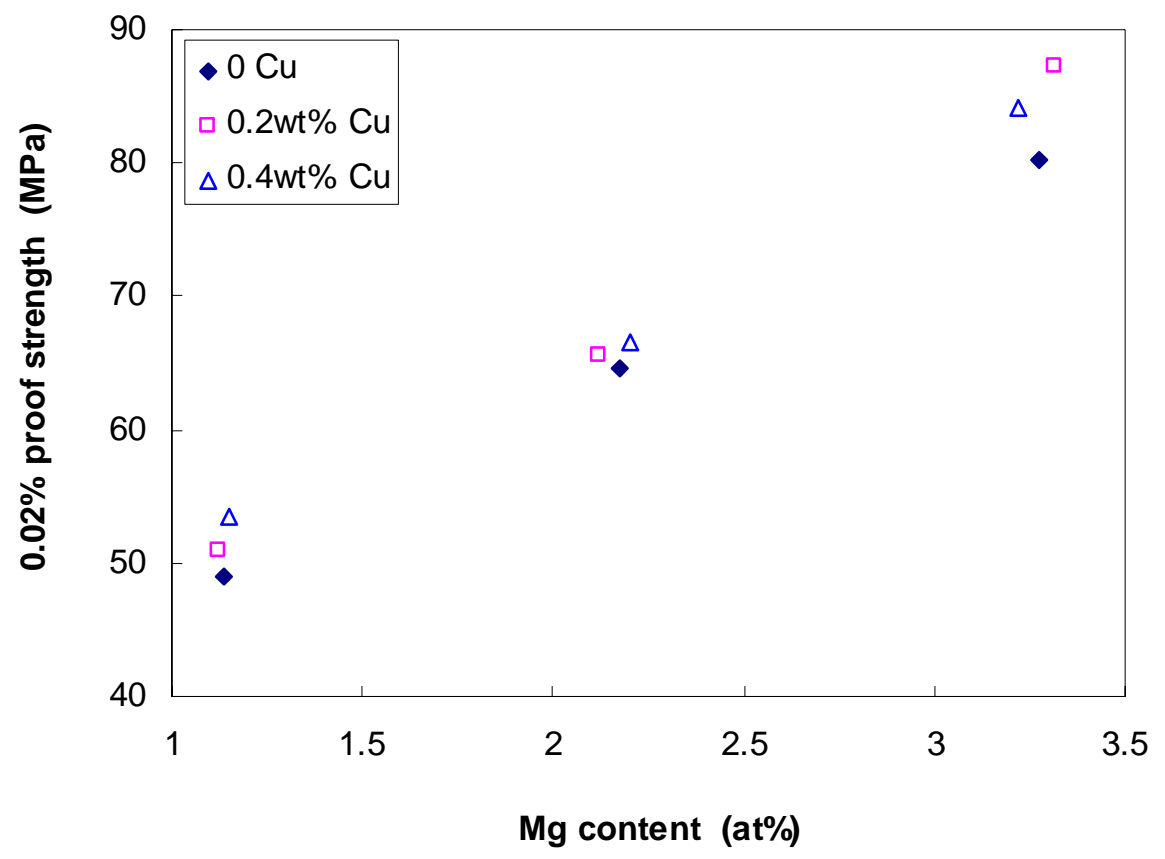

a.

Mg content (at\%) 


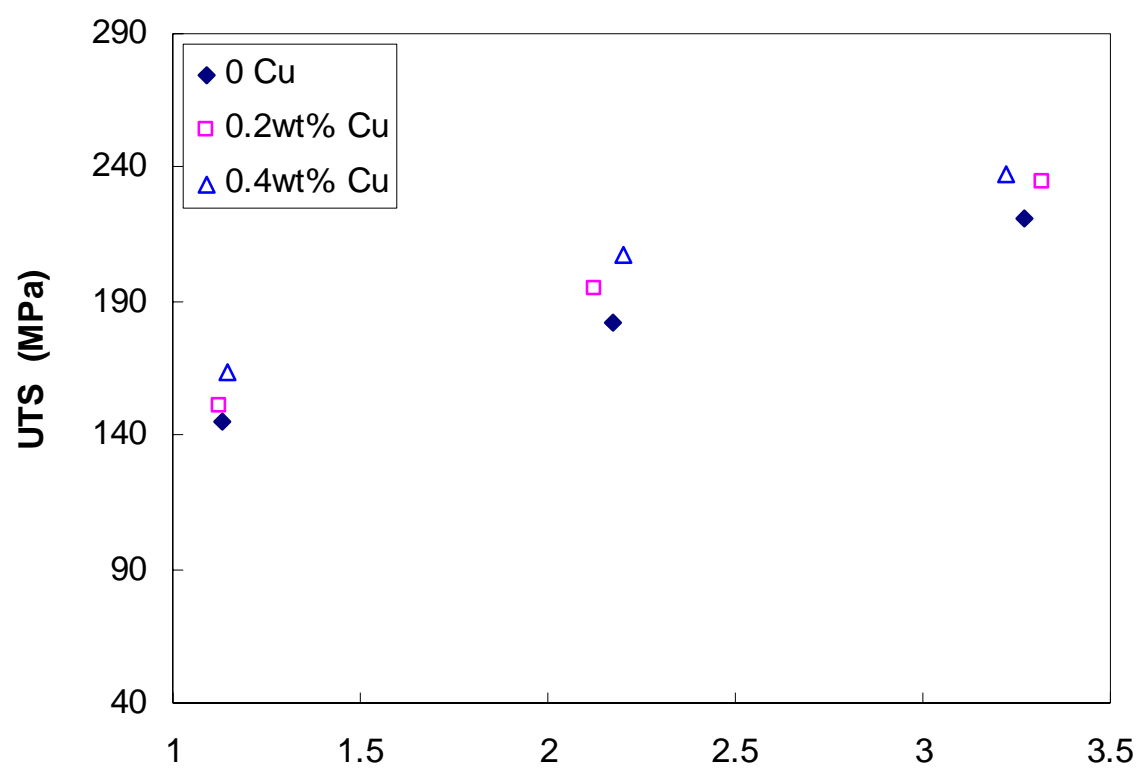

b.

Mg content (at\%)

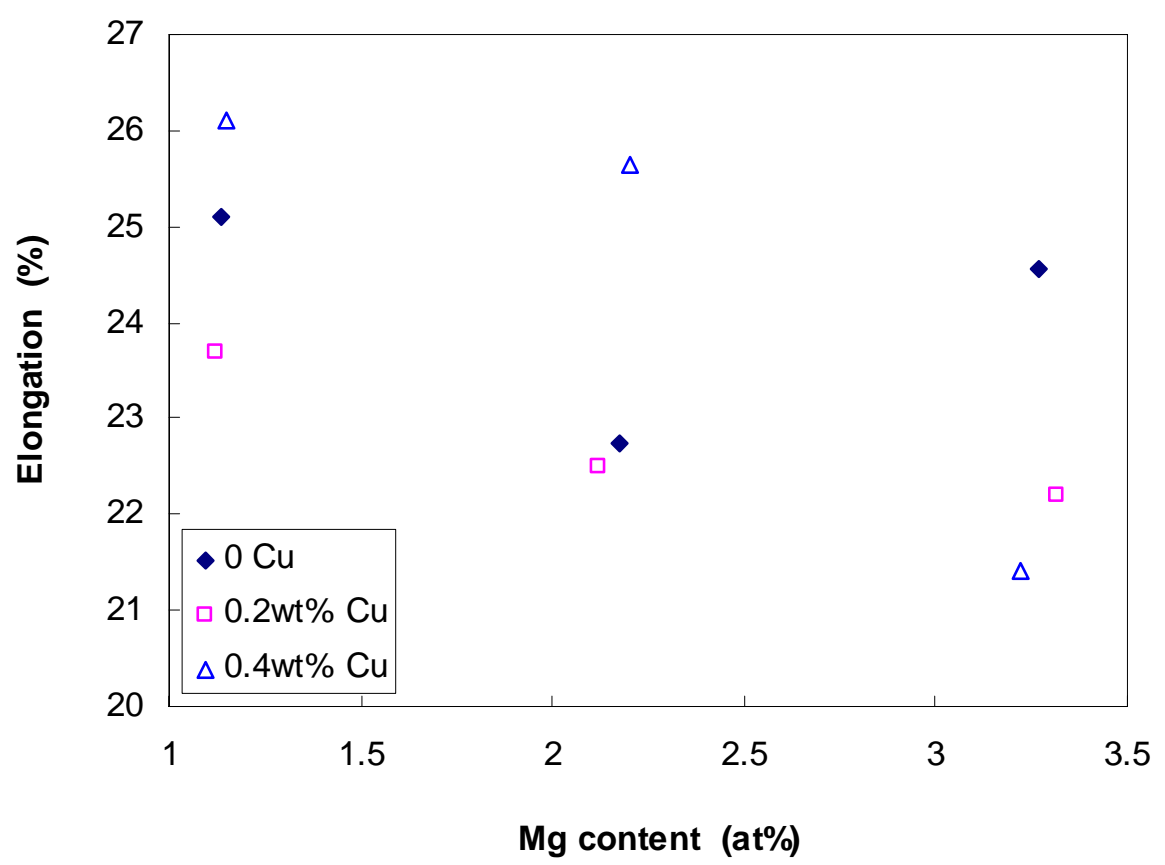

Fig. 3 Tensile test data vs. Mg contents for solution treated samples: a. $0.2 \%$ proof strength, $b$. UTS, c. elongation. 


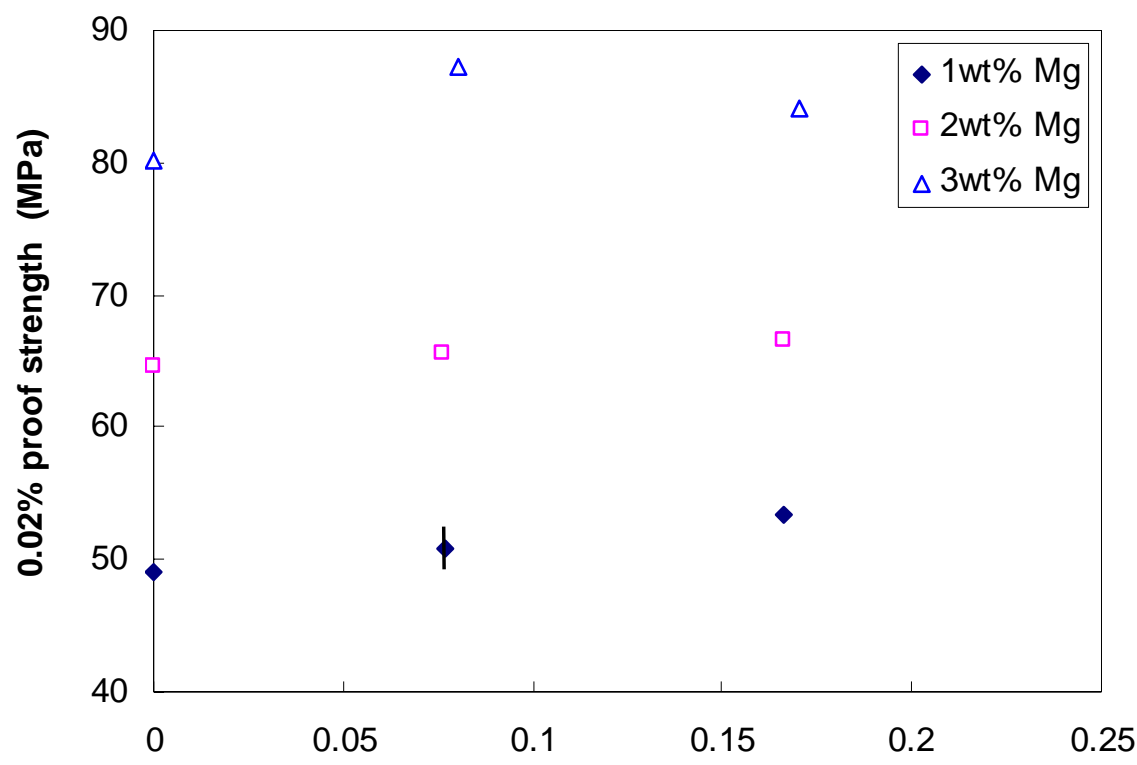

a.

Cu content (at\%)

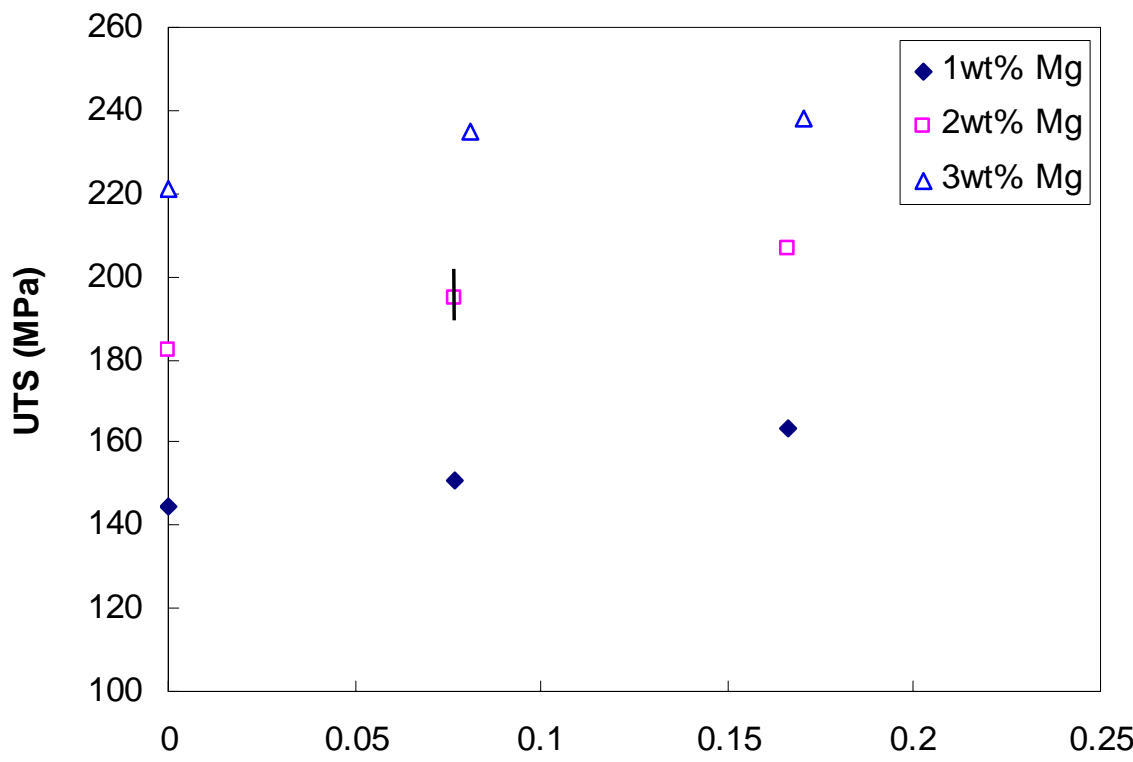

b.

Cu content (at\%) 


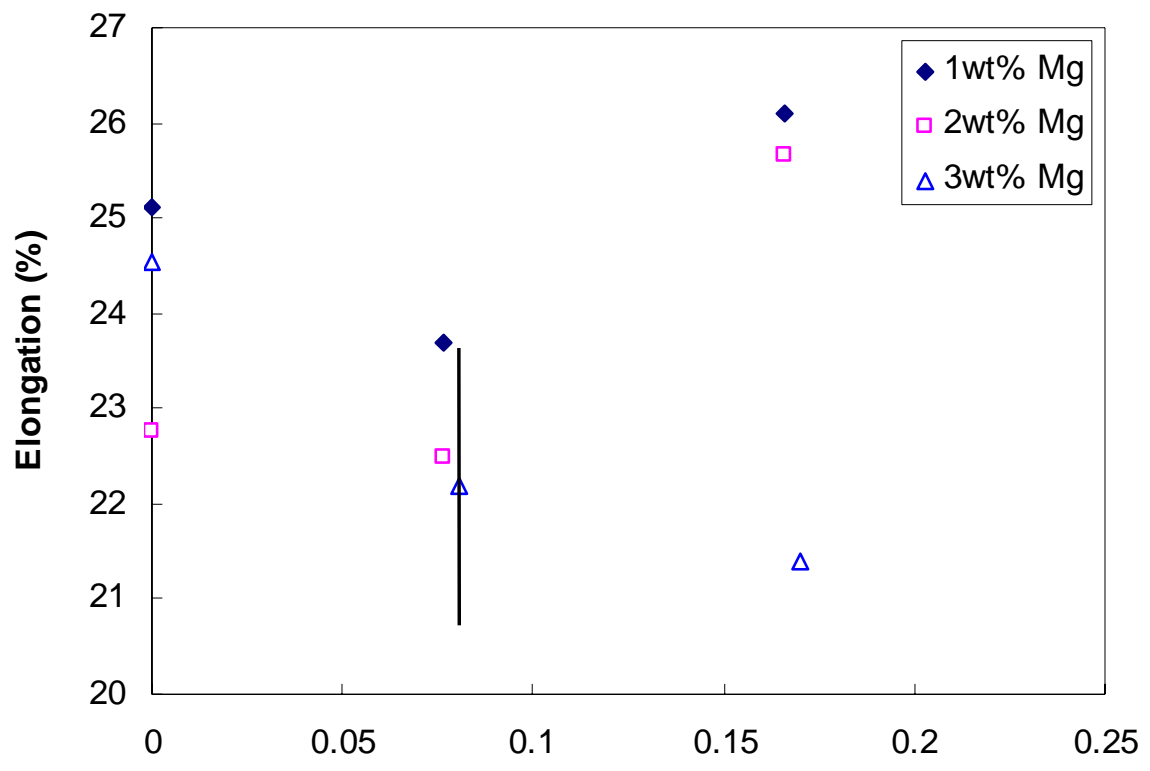

c.

Cu content (at\%)

Fig. 4 Tensile test data vs. Cu contents for solution treated samples: a. $0.2 \%$ proof strength, $b$. UTS, c. elongation. Bars on one point represent the average spread in measured values for each data point.

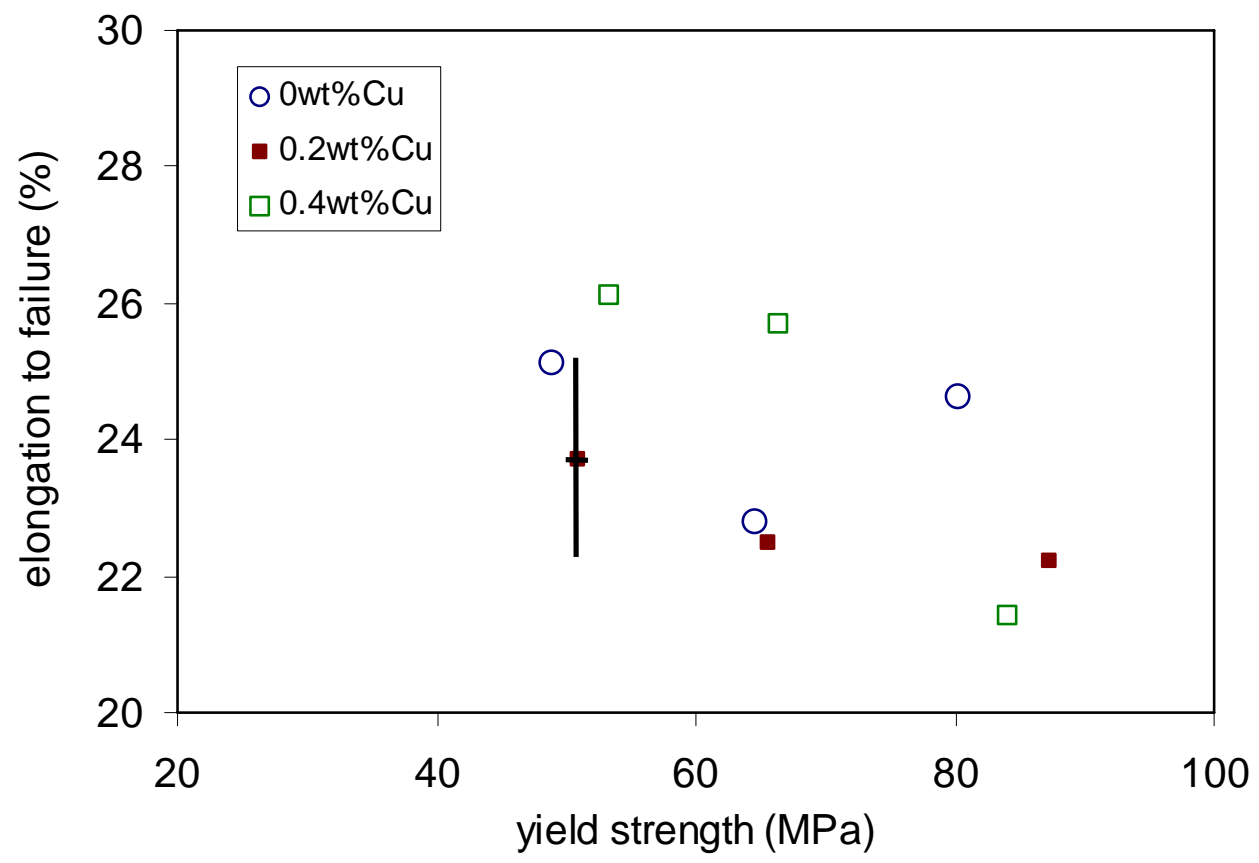

Fig. 5 Elongation to failure vs tensile yield strength for the 9 alloys in solution treated condition. Bars on one point represent the average spread in measured values for each data point. 


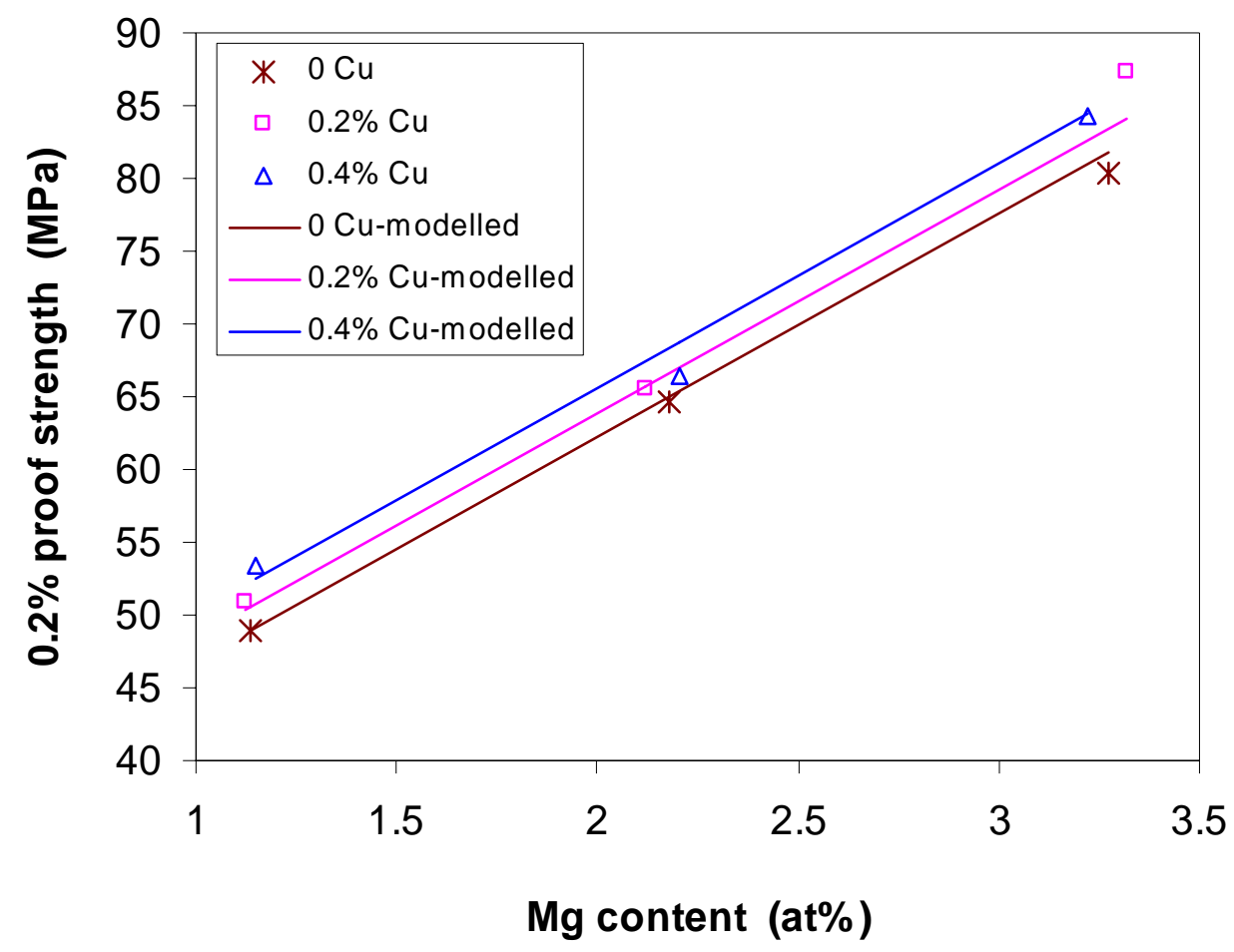

Fig. 6 Measured $0.2 \%$ proof strengths of solution treated alloys and their prediction.

The validity of Eq. 1 was tested by taking $n_{\mathrm{SS}}$ as $1,2 / 3$ or $1 / 2$ respectively, and fitting the $k$ parameters by the Least Square Method (LSM). Comparing the root mean squared error (RMSE) using different $n_{\mathrm{SS}}$ values, the lowest RMSE can be achieved when $n_{\mathrm{SS}}$ equals 1 . This finding is consistent with other analyses of solid solution strengthening by $\mathrm{Mg}$ [27,29].

After these parameters were determined, the yield strength of the solution treated alloys can be modelled using equations 1-2, and the predicted results and experimental results are shown in Fig. 6 . As shown in the figure, the predicted results reflect the experimental results very well with RMSE about $1.4 \mathrm{MPa}$. $k_{\mathrm{Mg}}$ determined this way is $590 \mathrm{MPa}$ (i.e. the CRSS increases by $5.9 \mathrm{MPa}$ per at $\% \mathrm{Mg}$ ), which compares to $540 \mathrm{MPa}$ from data given in Ref. [30], and an analysis of literature data from the ASM Handbook [31] provides 570MPa [15].

\subsection{Age hardening}

The hardness during isothermal ageing at $170^{\circ} \mathrm{C}$ for samples after solutionising at $500^{\circ} \mathrm{C}$ and $550^{\circ} \mathrm{C}$ are presented in Fig. 7. As shown in the figure, all $\mathrm{Cu}$-containing alloys and alloy $\mathrm{A} 1$ show age hardening. For $\mathrm{Cu}$-free alloys $\mathrm{A} 2$ and $\mathrm{A} 3$, no substantial age hardening was observed after solutionising at $500^{\circ} \mathrm{C}$, but after solutionising at $550^{\circ} \mathrm{C}$ these alloys do show age hardening (see Fig. $7 b)$. In interpreting the hardening data we need to consider that for the present alloy compositions ternary $\mathrm{Al}-\mathrm{Cu}-\mathrm{Mg}$ precipitates, precipitates based on the $\mathrm{Mg}_{2} \mathrm{Si}$ precipitation sequence and possibly quaternary Al-Mg-Si-Cu precipitates can cause strengthening (see e.g. [32]); whilst $\mathrm{Mg}$ contents are too low to allow precipitation of binary Al-Mg precipitates [33]. For instance, high-resolution transmission electron microscopy (HRTEM) studies of an $\mathrm{Al}-3 \mathrm{Mg}-0.4 \mathrm{Cu}-0.12 \mathrm{Si}(\mathrm{wt} \%)$ alloy during 
artificial ageing at $180^{\circ} \mathrm{C}$ has shown the presence of coherent precipitates (crystal structure is orthorhombic Cmmm with lattice parameters $a=1.2 \mathrm{~nm}, b=0.4 \mathrm{~nm}, c=0.4 \mathrm{~nm}$ ), which on further ageing transform into $\mathrm{S}$ phase [34]. Our results in (Fig. 7) show that a wide range of alloy compositions with very low $\mathrm{Si}$ and $\mathrm{Cu}$ contents are age hardenable. Age hardening for $\mathrm{Cu}$ free alloys occurs presumably through formation of $\mathrm{Mg}_{2} \mathrm{Si}$ type precipitates.

a.
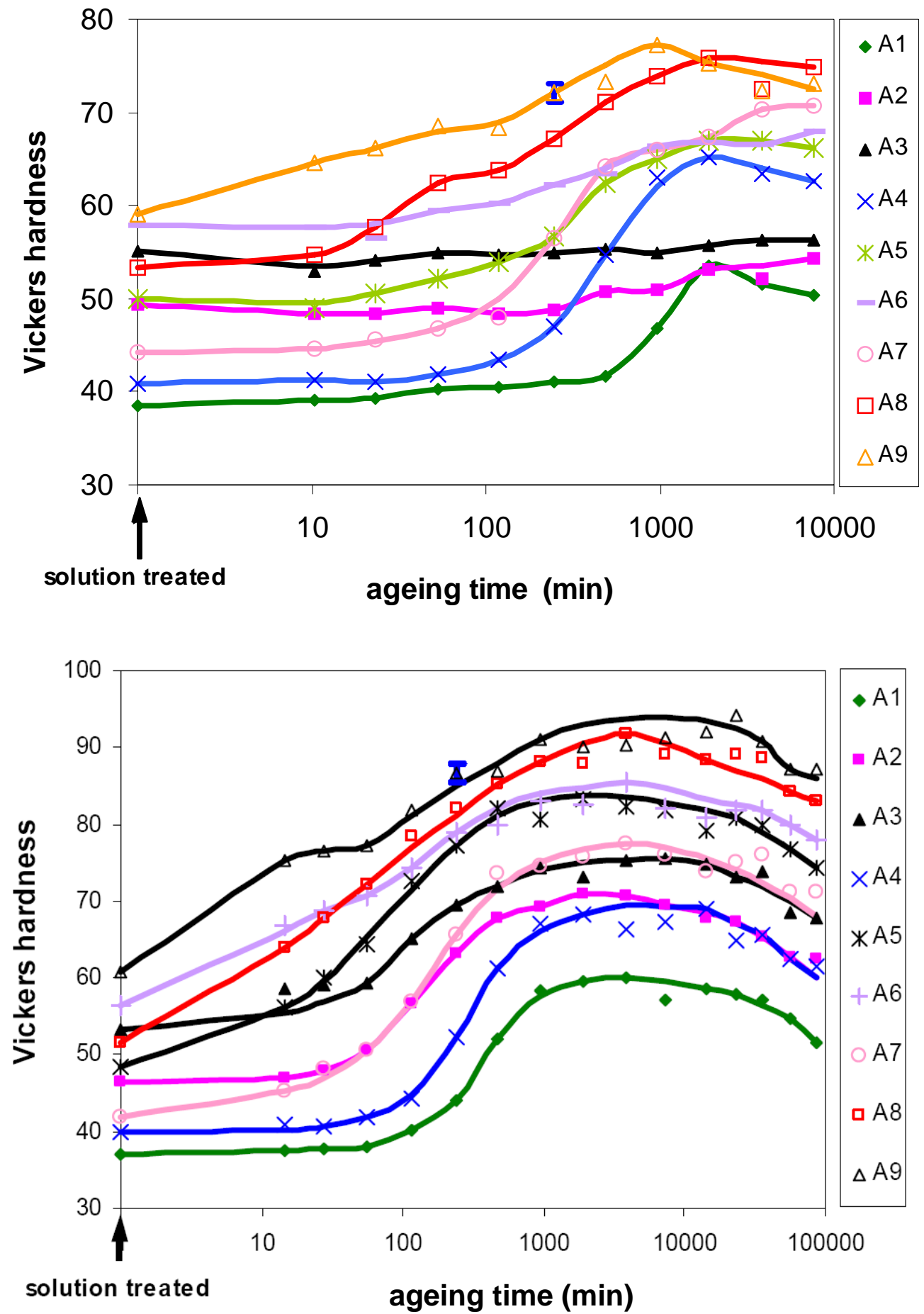

Fig. 7 Hardness during isothermal ageing at $170^{\circ} \mathrm{C}$ for solution treated samples solutionised 30 minutes at a) $500^{\circ}$, and b) $550^{\circ} \mathrm{C}$. In each graph, one error bar is shown, which indicates the average of the standard deviations of all tests reported in that graph. 
a.

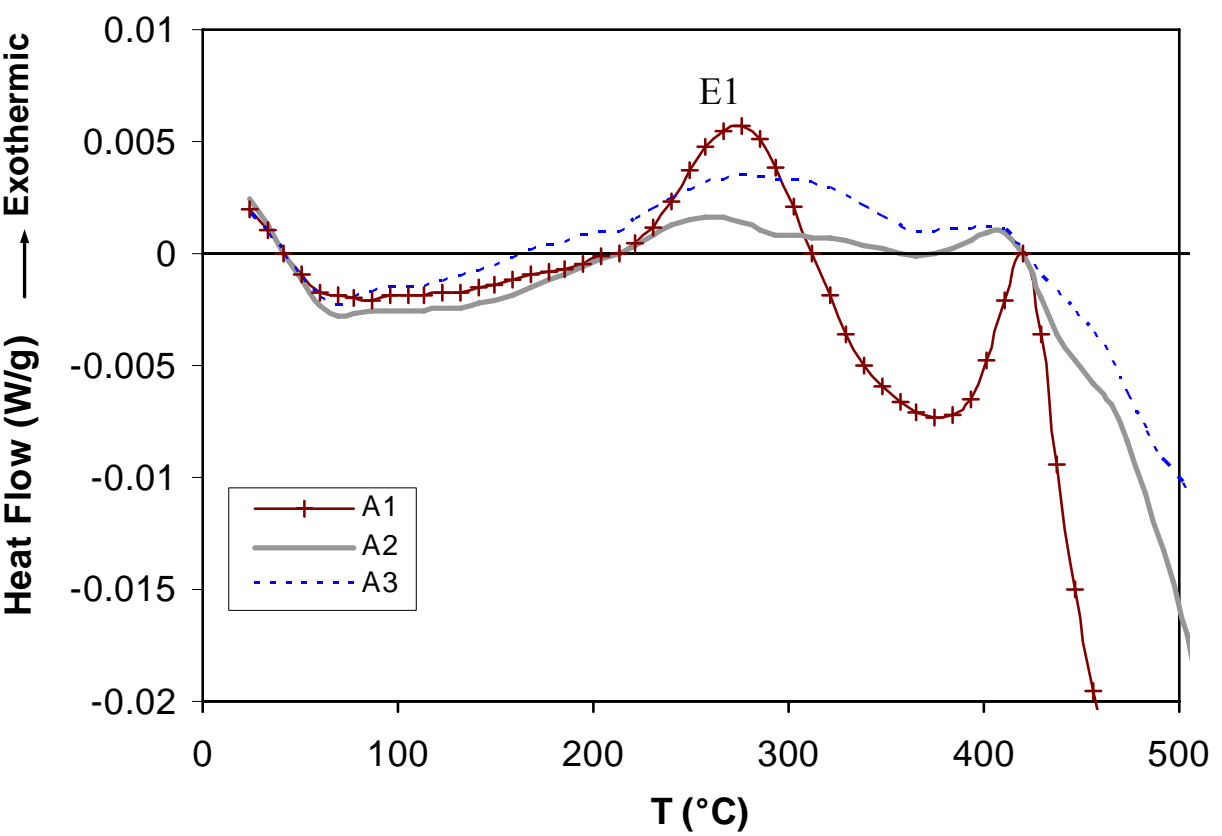

b.

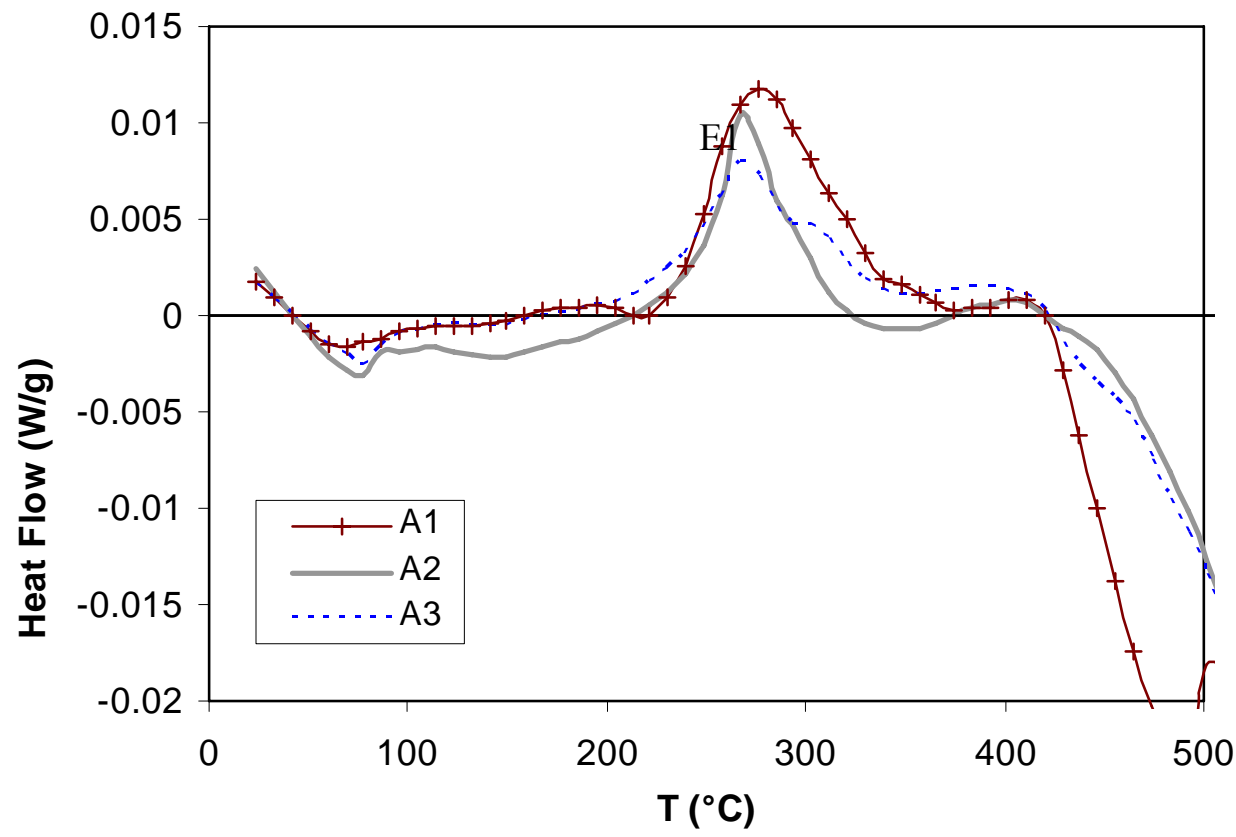

Fig.8 DSC data for $\mathrm{Cu}$-free alloys solutionised 30 minutes at a) $500^{\circ} \mathrm{C}$, b) $550^{\circ} \mathrm{C}$

To further study the reactions responsible for age hardening, DSC experiments were performed on the alloys in solution treated condition. For all alloys exothermic reactions indicative of precipitation reactions [16] occur, see Fig.8 and Fig. 9. To compare the isothermal ageing treatments with non-isothermal treatments by DSC in this study, we can use the temperature compensated time for a single thermally activated reaction, which is defined as [16]:

$$
\int \exp \left(-\frac{E_{a}}{R T}\right) d t=\exp \left(-\frac{E_{a}}{R T_{e q}}\right) t_{e q}
$$


a.

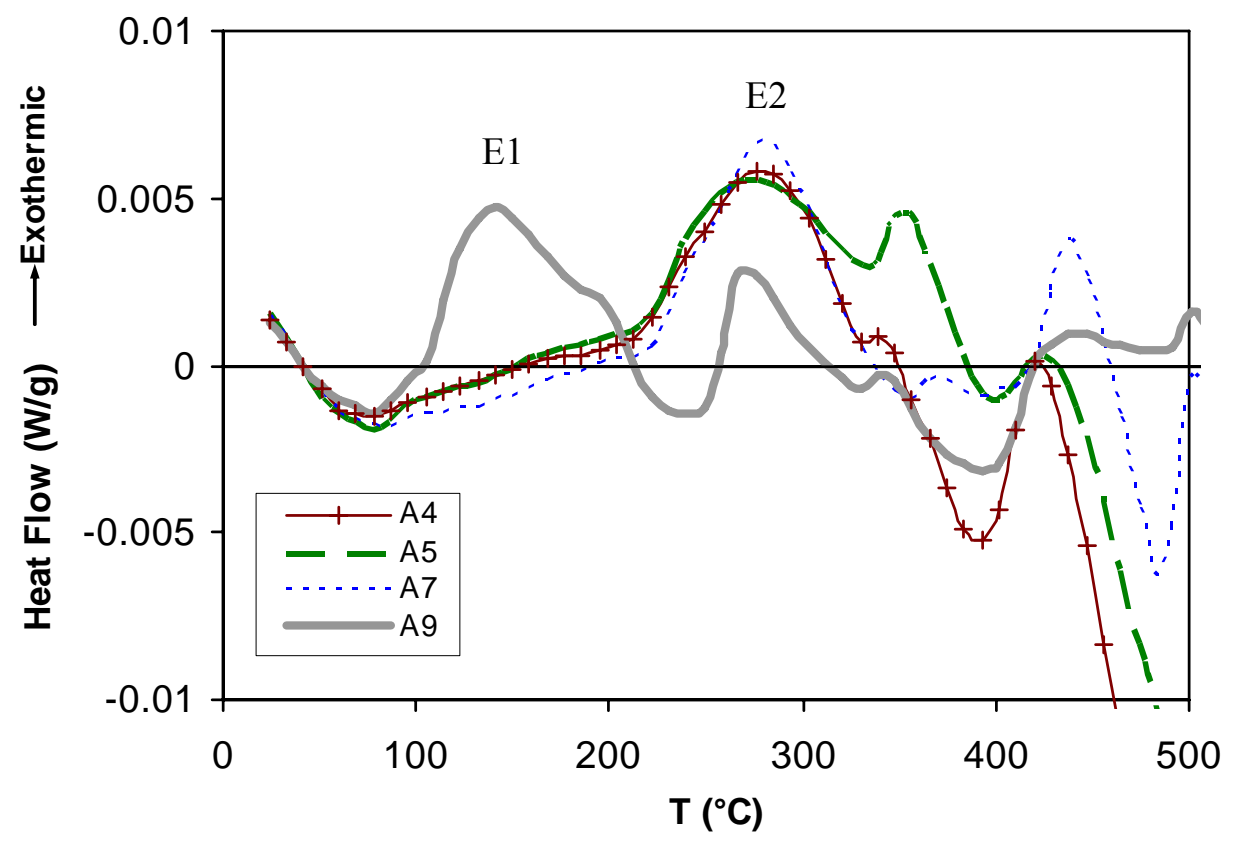

b.

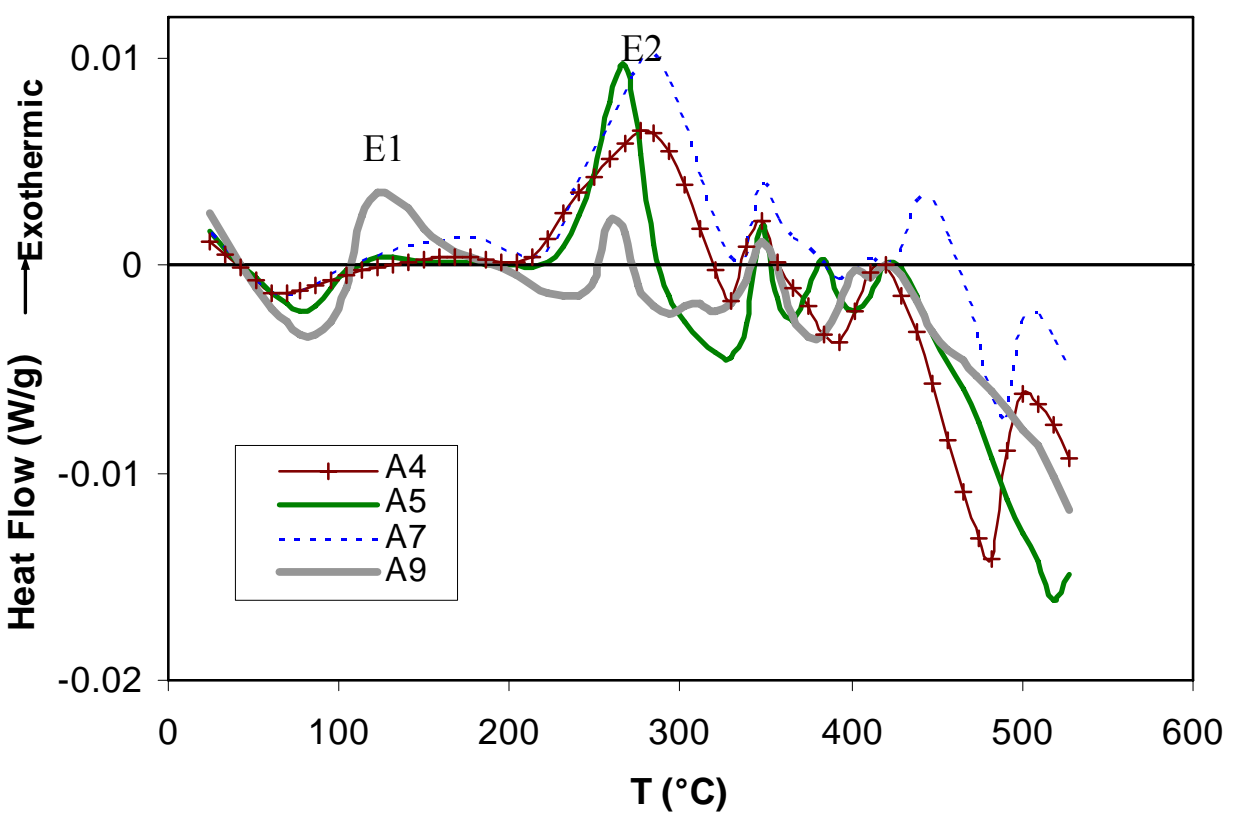

Fig. 9 DSC data for selected Cu-containing alloys solutionised 30 minutes at a) $500^{\circ} \mathrm{C}$, b) $550^{\circ} \mathrm{C}$

where $E_{\mathrm{a}}$ is the activation energy for the reaction (typically about 120 to $150 \mathrm{~kJ} / \mathrm{mole}$ for precipitation reactions involving $\mathrm{Si}, \mathrm{Mg}$ and $\mathrm{Cu}$ ), $R$ is the gas constant, $T$ is a temperature reached during a non-isothermal treatment, $T_{\text {eq }}$ and $t_{\text {eq }}$ are an equivalent temperature and time in an isothermal heat treatment, respectively. The integral can be approximated in several ways $[35,36]$. From temperature-compensated time calculations it can be deduced that reactions related to age hardening, which complete within several days isothermal ageing at $170^{\circ} \mathrm{C}$, are related to reactions occurring during DSC heating up to $350^{\circ} \mathrm{C}$ during DSC at a heating rate of $10^{\circ} \mathrm{C} / \mathrm{min}$. Hence, an analysis of DSC data up to $350^{\circ} \mathrm{C}$ may provide some interpretation of age hardening observed in the 
alloys. For Cu-free alloys, as shown in Fig. 8, an exothermic effect E1 at temperatures around 200$300^{\circ} \mathrm{C}$ occurs in solution treated alloy A1, regardless of the solutionising temperature. However, for alloys A2 and A3, it only occurs when the alloys are solutionised at $550^{\circ} \mathrm{C}$. This is consistent with the observation of age hardening of these three $\mathrm{Cu}$-free alloys. The effect $\mathrm{E} 1$ in Fig. 8, which is likely to be due to the precipitation of $\mathrm{Mg}_{2} \mathrm{Si}$ type precipitates, may be responsible for the age hardening observed during ageing for the $\mathrm{Cu}$-free alloys. For $\mathrm{Cu}$-containing alloys, the heat effects due to reactions become more complicated as shown in Fig. 9. An exothermic effect E2 at the temperatures around $200-300^{\circ} \mathrm{C}$ occurs in all solution treated $\mathrm{Cu}$-containing alloys, regardless of the solutionising temperature. This is consistent with the observation of age hardening detected in all the $\mathrm{Cu}$-containing alloys. This precipitation reaction is likely to be the main contributor to the age hardening of the alloys during isothermal ageing. For alloy A9 this effect is preceded by an exothermic effect at temperatures around $100-200^{\circ} \mathrm{C}$, indicated as E1 (see Fig. 9). It occurs in alloy A9, regardless of the solutionising temperature. This effect is consistent with the observation of rapid hardening within $1 \mathrm{~h}$ ageing (see Fig. $7 \mathrm{~b}$ ).

The SEM investigations (see section 3.1) showed that the cold rolled alloys with $1 \mathrm{wt} \% \mathrm{Mg}$, which were solutionised at $500^{\circ} \mathrm{C}$ prior to cold rolling do not contain coarse $\mathrm{Mg}_{2} \mathrm{Si}$ particles, whilst coarse $\mathrm{Mg}_{2} \mathrm{Si}$ particles were observed in the alloys with higher $\mathrm{Mg}$ content. This suggests that for the alloy with $1 \mathrm{wt} \% \mathrm{Mg}$ (alloy A1), $\mathrm{Mg}_{2} \mathrm{Si}$ particles can be dissolved at $500^{\circ} \mathrm{C}$ and thus $\mathrm{Si}$ becomes available for precipitation, and hence age hardening in this alloy is ascribed to the precipitation of $\mathrm{Mg}_{2} \mathrm{Si}$ particles and their precursors (e.g. $\beta$ " phase [37]). However, for alloys with Mg content in excess of $2 \mathrm{wt} \%$ very limited $\mathrm{Mg}_{2} \mathrm{Si}$ particles can be dissolved at $500^{\circ} \mathrm{C}$ and thus less $\mathrm{Si}$ is in solution and hence no substantial age hardening can be observed in alloys $\mathrm{A} 2$ and $\mathrm{A} 3$. However, the $\mathrm{Mg}_{2} \mathrm{Si}$ particles can be dissolved at $550^{\circ} \mathrm{C}$, hence these alloys show age hardening after solutionising at $550^{\circ} \mathrm{C}$. This interpretation of $\mathrm{Mg}_{2} \mathrm{Si}$ solubility for these alloys in the 500 to $550^{\circ} \mathrm{C}$ range is consistent with thermodynamic modelling predictions (see Table 2) and DSC analysis (see above). Thus the age hardening capability of these alloys is very sensitive to the combination of $\mathrm{Mg}$ content and solution treatment temperatures, which determine the amount of $\mathrm{Si}$ that is available for precipitation hardening.

All alloys show substantial age hardening after solutionising at $550^{\circ} \mathrm{C}$ (Fig. $7 \mathrm{~b}$ ). Compared with the results of ageing after solutionising at $500^{\circ} \mathrm{C}$, the maximum hardness reached is higher and the hardening occurs at an increased rate. This enhanced age hardening rate may be due to an increased density of vacancies introduced at the higher solution temperature, which provides more nucleation sites for precipitation. It is interesting to note that after solutionising at $550^{\circ} \mathrm{C}$, most $\mathrm{Cu}$-containing alloys show rapid hardening within $1 \mathrm{~h}$ ageing (Fig. $7 \mathrm{~b}$ ). But after solutionising at $500^{\circ} \mathrm{C}$, only alloy A9 shows rapid hardening (Fig. 7a). This rapid hardening is though to be due to either $\mathrm{Cu}-\mathrm{Mg}$ coclusters [38,39] or S" phase [34] and is also consistent with the DSC analysis (see above).

We further compared the observed age hardening and the assumed existence of two precipitation sequences with predictions based on the theory of hardening through hampering of dislocation movement by obstacles. This theory predicts that in the absence of significant dislocation hardening the yield strength of a polycrystalline alloy is given by [40,41]:

$$
\sigma_{\mathrm{y}}=\Delta \sigma_{\mathrm{gb}}+M \tau_{\mathrm{tot}}=\Delta \sigma_{\mathrm{gb}}+M\left[\tau_{0}+\Delta \tau_{\mathrm{ss}}+\left(\Delta \tau_{\mathrm{p}, \mathrm{A}}^{2}+\Delta \tau_{\mathrm{p}, \mathrm{B}}{ }^{2}\right)^{1 / 2}\right]
$$


where $\tau_{\text {tot }}$ is the total CRSS of the grains, $\Delta \tau_{\mathrm{p}, \mathrm{A}}$ and $\Delta \tau_{\mathrm{p}, \mathrm{B}}$ are the increments in CRSS of the grains due to precipitate type $\mathrm{A}$ and $\mathrm{B}$, which in our alloys are the $\mathrm{S}$ phase and the $\mathrm{Mg}_{2} \mathrm{Si}$ phase and its precursors. In our alloys the precipitates are approximately rod shaped, and for these particles it holds [42]:

$$
\Delta \tau_{\mathrm{p}, \mathrm{rod}}=\frac{0.112 \mu_{\mathrm{Al}} b}{D_{\mathrm{r}}} \ln \left(\frac{1.316 D_{\mathrm{r}}}{r_{\mathrm{o}}}\right)\left(f^{1 / 2}+0.94 f+2.44 f^{3 / 2}\right)
$$

where $\mu_{A l}$ is the shear modulus of aluminium, $f$ is the volume fraction of the rod-shaped precipitates, $D$ is the diameter of the obstacle, $b$ is the Burgers vector and $r_{\mathrm{o}}$ is the inner cut-off radius for calculation of the dislocation line tension, which is generally considered equal to the Burgers vector. For the very small volume fractions of precipitate encountered here we may approximate:

$$
\Delta \tau_{\mathrm{p}, \mathrm{rod}} \cong \frac{0.112 \mu_{\mathrm{Al}} b}{D_{\mathrm{r}}} \ln \left(\frac{1.316 D_{\mathrm{r}}}{r_{\mathrm{o}}}\right) f^{1 / 2}
$$

In a further approximation we may consider that the diameter and aspect ratio of the precipitates at the peak of strength does not depend significantly on the alloy composition, and provided the two precipitates types reach their peak strengthening contribution at approximately the same ageing time, the precipitate strengthening contribution is proportional to the volume fractions as follows:

$$
\left(\Delta \tau_{\mathrm{p}, \mathrm{A}}^{2}+\Delta \tau_{\mathrm{p}, \mathrm{B}}^{2}\right)^{1 / 2}=\left(B_{\mathrm{A}} f_{\mathrm{A}}+B_{\mathrm{B}} f_{\mathrm{B}}\right)^{1 / 2}
$$

where $B_{\mathrm{A}}$ and $B_{\mathrm{B}}$ are constants depending on the diameter and aspect ratio of the precipitates at peak strength. This model for peak strength (Eq. 6 and 7) was fitted to the observed data on hardness increment caused by ageing (which ranges from 0 to $39 \mathrm{HV}$ ) using the assumption that hardness is proportional to yield strength. To this end we assume that the precipitate stoichiometry is independent of alloy composition and fit $B_{\mathrm{A}}$ and $B_{\mathrm{B}}$ to the data. A good correlation (standard deviation $3 \mathrm{HV}$, which is $8 \%$ of the observed range) of modelled and measured peak hardness (from Fig. 7a) is obtained. (It should be noted that when alloy A5, which appears to have a somewhat high peak hardness, is omitted the standard deviation improves to 2HV.) This good correlation shows that the observed peak hardness values are indeed consistent with the present interpretation of two precipitates being responsible for peak hardness. Higher than predicted hardening increments are observed for alloys A5, A8 and A7 (in order of highest deviations). These alloys are close together in terms of $\mathrm{Mg}: \mathrm{Cu}: \mathrm{Si}$ ratios which might hint at further details relevant to precipitation hardening beyond the simplified approximations considered here. It might for instance hint at the occurrence of quaternary precipitates.

It should be noted that Vooijs et al. [43] have studied precipitation in solution treated (at $610^{\circ} \mathrm{C}$ ) and solution treated and subsequently cold rolled Al-0.9Mn-0.97Mg-0.18Cu-0.0.46Fe-0.29Si and Al-1.04Mn-1.36Mg-0.30Cu-0.31Fe-0.17Si alloys (in $\mathrm{wt} \%$ ) by using thermoelectric power and resistivity measurements. In agreement with our analysis they concluded that $\mathrm{S}$ precipitates $\left(\mathrm{Al}_{2} \mathrm{CuMg}\right)$ form at ageing temperatures below $225^{\circ} \mathrm{C}$ but they stated that only a very small amount of $\mathrm{Mg}_{2} \mathrm{Si}$ forms. Our analysis indicates that for the very similar alloy A4, Si containing precipitates are significant, with the strengthening contributions from the two types of precipitates of similar 
order of magnitude. One explanation may be the larger Mn content of Vooijs et al.'s alloy which may lead to increased amounts of the Si containing $\mathrm{Al}_{12}(\mathrm{Fe}, \mathrm{Mn})_{3} \mathrm{Si}$ remaining undissolved during the solution treatment. We would also note here that the analysis in [43] using a combination of thermoelectric power and resistivity measurements might produce some inaccuracy with regards to the ratio of $\mathrm{S}$ and $\mathrm{Mg}_{2} \mathrm{Si}$ precipitates due to a non stoichiometric composition of the $\mathrm{Mg}_{2} \mathrm{Si}$ precipitates and electron scattering effects by very small precipitates.

\section{Conclusions}

Nine Al-(1-3)Mg-(0-0.4)Cu-0.15Si-0.25Mn (in wt\%) alloys with potential and existing applications in both packaging and automotive industries have been investigated. Tensile testing at room temperature of solution treated samples showed that solution strengthening in good approximation increases linearly with $\mathrm{Mg}$ content. In solution treated condition, the alloys have elongation to failure between 22 and 26\%; Cu additions have a very limited influence on elongation. Hardness testing and DSC analysis of solution treated and aged samples indicate that $\mathrm{Mg}_{2} \mathrm{Si}$ phase precipitates contribute to age hardening of $\mathrm{Cu}$-free alloys, whilst both $\mathrm{Mg}_{2} \mathrm{Si}$ phase and $\mathrm{S}$ $\left(\mathrm{Al}_{2} \mathrm{CuMg}\right)$ phases contribute to that of $\mathrm{Cu}$-containing alloys. The age hardening capability is critically influenced by solution treatment temperature: increasing the solution treatment temperature from 500 to $550^{\circ} \mathrm{C}$ results in a marked increase in rate of hardening for $\mathrm{Cu}$ containing alloys and solution treatment at about $550^{\circ} \mathrm{C}$ or higher is needed to allow $\mathrm{Mg}_{2} \mathrm{Si}$ phase precipitation during ageing in $\mathrm{Cu}$-free alloys with $\mathrm{Mg}$ content of about $2 \%$ or higher.

\section{Acknowledgements}

The authors would like to thank Alcan International for providing the alloys and support for this work, and thank Drs G. Mahon (currently at Innoval), M. Hao and S. Court for their technical input.

\section{References}

[1] J. Courbon, Mater. Sci. Forum, 331-337 (2000) 17.

[2] J. Courbon, Scr. Mater. 48 (2003) 1519-1524.

[3] K. Koyama, S. Urayoshi, T. Tanaka, Furukawa Review 18 (1999) 97.

[4] G.J. Marshall, Mater. Sci. Forum 217-222 (1996) 19.

[5] G.B. Burger, A.K. Gupta, P.W. Jeffrey, D.J . Lloyd, Mater. Charact. 35 (1995) 23.

[6] P. Ratchev, B. Verlinden, P. van Houtte, P. de Smet, Mater. Sci. Eng. A 222 (1997) 189.

[7] Herdawandi Halim, D.S. Wilkinson, M. Niewczas, Acta Mater. 55 (2007) 4151-4160.

[8] S.A. Court, K.M. Gatenby, D.J. Lloyd, Mater. Sci. Eng. A 319 (2001) 443 -447.

[9] Y. Birol, Mater. Sci. Techn. 22 (2006) 987-994.

[10] P. Ratchev, B. Verlinden, P. de Smet, P. van Houtte, Acta Metall. Mater. 46 (1998) 3523.

[11] D.T.L. Alexander, A.L. Greer, Acta Mater. 50 (2002) 2571 -2583.

[12] R.K. Bolingbroke, G.J. Marshall, R.A. Ricks, R.A., the 3rd International conference on Aluminium alloys, L. Arnberg, O. Lohne, E. Nes, N. Ryum (Eds), 1992, Trondheim, Norway, p. 285

[13] B. Verlinden, A.-M. Zahra, Mater. Sci. Forum 426-432 (2003) 423.

[14] M.J. Starink, A. Dion, Thermochim. Acta 417 (2004) 5-11.

[15] S.C. Wang, Z. Zhu, M.J. Starink, J. Microscopy 217 (2005) 174-178.

[16] M.J. Starink, Int. Mater. Rev. 49 (2004) 191-226.

[17] M. Dehmas, P. Weisbecker, G. Geandier, P. Archambault, E. Aeby-Gautier, J. Alloys Compounds 400 (2005) 116-124. 
[18] N.A. Lange, G.M. Forker, Lange's Handbook of Chemistry. (10th edition). McGraw-Hill Book Company: New York (1967).

[19] C. Blanc, Y. Roques, G. Mankowski, Corrosion Sci. 40 (1998) 1019.

[20] M.C. Sneed, R.C. Brasted, The elements and compounds of group IVA (Vol.7). Comprehensive inorganic chemistry. New York: D. Van Nostrand Company, INC. (1958).

[21] J. Friedel, Dislocations. London: Pergamon Press Ltd. (1964).

[22] A.J.E. Foreman, M.J. Makin, Phil. Mag. 14 (1966) 911-924.

[23] F. Nabarro, Theory of crystal dislocations. Oxford: University Press (1967).

[24] L.A. Gypen, A. Deruyttere, J. Mater. Sci. 12 (1977) 1028.

[25] P. Gomiero, Y. Brechet, F. Louchet, A. Tourabi, B. Wack, Acta Metall. Mater. 40 (1992) 857.

[26] P. Haasen: in Physical Metallurgy, 4th ed., R.W. Cahn and P. Haasen, eds., Elsevier Science BV, 1996, pp. 2009-68.

[27] O. Nijs, E. Sjolander, B. Holmedal, H.E. Ekstrom, E. Nes, Metall Mater Trans 37A (2006) 1999 2006.

[28] B. Clausen, T. Lorentzen, T. Leffers, Acta Mater. 46 (1998) 3087.

[29] J. Yan, PhD thesis, University of Southampton, 2006.

[30] D.J. Lloyd, S.A. Court, Mater. Sci. Technol. 19 (2003) 1349.

[31] Davis, J.R., ASM Specialty Handbook: Aluminium and Aluminium Alloys. ASM International (1993).

[32] D.J. Chakrabarti, D.E. Laughlin, Prog. Mater. Sci. 49 (2002) 389-410

[33] M.J. Starink, A.-M. Zahra, Phil. Mag. A 76 (1997) 701-714.

[34] L. Kovarik, P. I. Gouma, C. Kisielowski, S. A. Court, M. J. Mills, Acta Mater. 52 (2004) 2509-2520.

[35] M.J. Starink, Thermochim Acta 404 (2003) 163.

[36] M.J. Starink, J. Mater. Sci. 42 (2007) 483-489.

[37] M.A. van Huis, J.H. Chen, M.H.F. Sluiter, H.W. Zandbergen, Acta Mater. 55 (2007) 2183-2199.

[38] M.J. Starink, N. Gao, L. Davin, J. Yan, A. Cerezo, Phil. Mag. 85 (2005) 1395-1418.

[39] M.J. Starink, N. Gao, J.L. Yan, Mater. Sci. Eng. A 387-389 (2004) 222-226.

[40] M.J. Starink, A. Deschamps, S.C. Wang, Scr. Mater, 2007, in press

[41] M.J. Starink, S.C. Wang, Acta Mater. 51 (2003) 5131-5150

[42] I.N. Khan, M.J. Starink, J.L. Yan, Mater Sci Eng A, 2007, in press

[43] S. Vooijs, B. Davenport, I. Todd, S. van der Zwaag, Philosph Mag A 81 (2001) 2059 